\title{
Differential hydrogen isotopic ratios of Sphagnum and vascular plant biomarkers in ombrotrophic peatlands as a quantitative proxy for precipitation-evaporation balance
}

\author{
Jonathan Nichols $^{\mathrm{a}}$, Robert K. Booth ${ }^{\mathrm{b}}$, Stephen T. Jackson ${ }^{\mathrm{c}}$, \\ Elise G. Pendall ${ }^{\mathrm{c}}$, Yongsong Huang ${ }^{\mathrm{a}, *}$ \\ ${ }^{a}$ Brown University, Department of Geological Sciences, Providence, RI, USA \\ ${ }^{\mathrm{b}}$ Lehigh University, Department of Bethlehem, PA,USA \\ ${ }^{\mathrm{c}}$ University of Wyoming, Department of Botany, Laramie, WY, USA
}

Received 27 May 2009; accepted in revised form 10 November 2009; available online 15 November 2009

\begin{abstract}
We have developed a new approach to quantitatively reconstruct past changes in evaporation based on compound-specific hydrogen isotope ratios of vascular plant and Sphagnum biomarkers in ombrotrophic peatland sediments. We show that the contrast in H isotopic ratios of water available to living Sphagnum (top $20 \mathrm{~cm}$ ) and in the rooting zone of peatland vascular plants can be used to estimate " $f$ "- the fraction of water remaining after evaporation. Vascular plant leaf waxes record $\mathrm{H}$ isotopic ratios of acrotelm water, which carries the $\mathrm{D} / \mathrm{H}$ ratio signature of precipitation and is little affected by evaporation, whereas the Sphagnum biomarker, $\mathrm{C}_{23} n$-alkane, records $\mathrm{H}$ isotopic ratios of the water inside its cells and between its leaves, which is strongly affected by evaporation at the bog surface. Evaporation changes can then be deduced by comparing $\mathrm{H}$ isotopic ratios of the two types of biomarkers. We calibrated D/H ratios of $\mathrm{C}_{23} n$-alkane to source water with lab-grown $S p h a g$ num. We also tested our isotopic model using modern surface samples from 18 ombrotrophic peatlands in the Midwestern United States. Finally, we generated a 3000-year downcore reconstruction from Minden Bog, Michigan, USA. Our new record is consistent with records of other parameters from the same peatland derived from different proxies and allows us to differentiate precipitation supply and evaporative loss.
\end{abstract}

(C) 2009 Elsevier Ltd. All rights reserved.

\section{INTRODUCTION}

The balance of precipitation and evaporation is a critical climate parameter that has enormous impact on natural vegetation and agriculture, as well as drinking water and sanitation infrastructure (IPCC WG II, 2007). It is an integral part of the climate system that can be estimated in models (Shindell et al., 2006), but has been difficult to quantify in climate reconstructions extending beyond the instrumental record. Past hydroclimatological changes have been

\footnotetext{
* Corresponding author. Tel.: +1 4018633822.

E-mail address: yongsong huang@brown.edu (Y. Huang).
}

reconstructed using various paleolimnological methods (Last and Smol, 2002). For example, lake level reconstructions based on paleo-shorelines provide estimates of past hydrologic balance, but temporal resolution is often low and only large, persistent hydrological changes are readily recognized in the reconstructed records (e.g., Abbott et al., 2000; Shuman et al., 2004). Other methods, such as mineralogical analysis or microfossil assemblages provide qualitative information on past hydrological changes ( $\mathrm{Yu}$ and Ito, 1999; Alvarez Zarikian et al., 2005). Paleoindicators that reflect water balance in a lake, such as diatom-inferred salinity, can be affected by parameters other than just regional climate changes, such as changes in local catchment hydrology (Fritz, 1996). Annual reconstructions of drought severity have been produced for recent centuries 
from tree ring records throughout North America (Cook et al., 1999, 2004). However, the drought-sensitivity, site density, and sampling depth of the tree ring record vary in time and space, and are temporally shallow in the humid regions of eastern North America.

Because they are isolated from the local groundwater, all moisture input to ombrotrophic peatlands comes from precipitation. For this reason, ombrotrophic bogs are very sensitive to changes in the balance between precipitation and evaporation, and the interpretation of past climate changes from peat stratigraphy is not confounded by changes in local groundwater hydrology (Blackford, 2000). Sediments from Sphagnum-dominated ombrotrophic peatlands have been widely used as archives of hydrologic balance because of the controlling role of peatland hydrology over the vegetation assemblage (Barber et al., 2003), microbial communities (Booth, 2007), and degree of decomposition of organic material at the surface (Caseldine et al., 2000). Paleoenvironmental indicators such as testate amoebae, plant macrofossils, measurements of humification, and plant biomarker distributions have been used to extract this hydrologic information from the sediment record (Barber et al., 2003; Booth and Jackson, 2003; Booth et al., 2006; Nichols et al., 2006). However, despite the usefulness of these paleohydrologic indicators for inferring general dry and wet conditions, direct conversion of these measurements to quantitative estimates of precipitation or evaporation is difficult.

The prime purpose of our investigation is to develop a method to quantitatively reconstruct precipitation - evaporation balance from ombrotrophic sediments. We have developed a model to quantify the fraction of water evaporated from the surface of a peatland through time. We tested this model for proof-of-concept using conjunctive stable hydrogen and oxygen isotope ratio measurements of water collected from modern peatland surfaces. We used Sphagnum tissue samples collected from peatlands and grown in the laboratory to constrain hydrogen isotope frac- tionation between water and lipids. We then applied our evaporation model to measurements of hydrogen-isotope ratios of Sphagnum and vascular plant leaf waxes extracted from the sediments of Minden Bog, an ombrotrophic peatland in eastern Michigan. Our results indicate that the hydrogen isotopic difference between the biomarkers of vascular plants and Sphagnum can be used as a proxy for past changes in evaporation.

\section{SAMPLES AND METHODS}

We studied two sets of samples: one of modern water and plant samples from 18 peatlands from the Midwestern United States, and the other from a sediment core from Minden Bog, Michigan, USA $\left(43^{\circ} 36^{\prime} 43^{\prime \prime} \mathrm{N}, 82^{\circ} 50^{\prime} 10^{\prime \prime} \mathrm{W}\right)$. The first set of samples was used for developing and validating our isotopic model, while the second set of samples for testing our proxy reconstruction against traditional proxies and general climate scenarios.

Fig. 1 shows the locations of peatland samples used for model development, including Minden Bog. From each site in the model development set, three types of samples were collected: "sphagnum water," "acrotelm water," and Sphagnum plant samples. For the purposes of this paper, we will use "sphagnum" to refer to water samples, and "Sphagnum" to refer to the plant itself. The cartoon in Fig. 2 shows the locations of the different sample types in the peatland. The first type of sample, sphagnum water, was squeezed from the living Sphagnum, approximately, the top $20 \mathrm{~cm}$ or less. This is the zone over which the capillary action of Sphagnum hyaline cells is effective. Water below this depth cannot be used by Sphagnum for photosynthesis (Charman, 2002). To sample this water type, Sphagnum at each site was plucked from the surface of the peatland. Water clinging to the outside was dabbed off with paper toweling. The Sphagnum was then squeezed with a coarse $(\sim 2 \mathrm{~mm})$ sieve into a container. This method assured that the water being sampled was from inside the

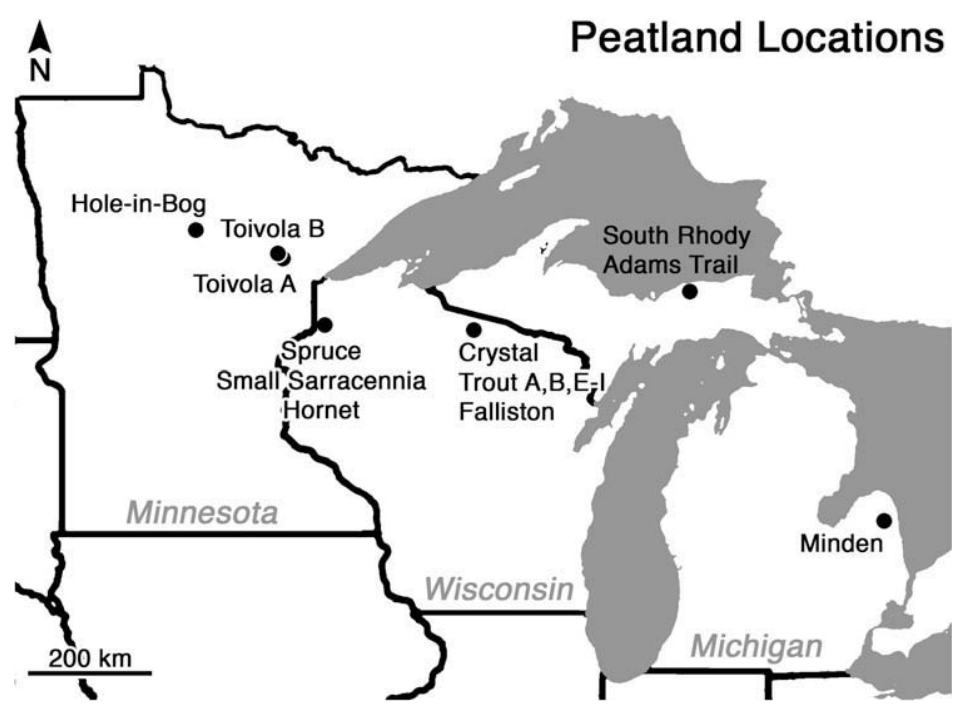

Fig. 1. Map of the upper Midwestern United States showing the locations of peatland used in the surface model development sample set, as well as the location of Minden Bog, where the core was collected. Multiple labels indicate that several peatlands are closer together than the size of the marker. 


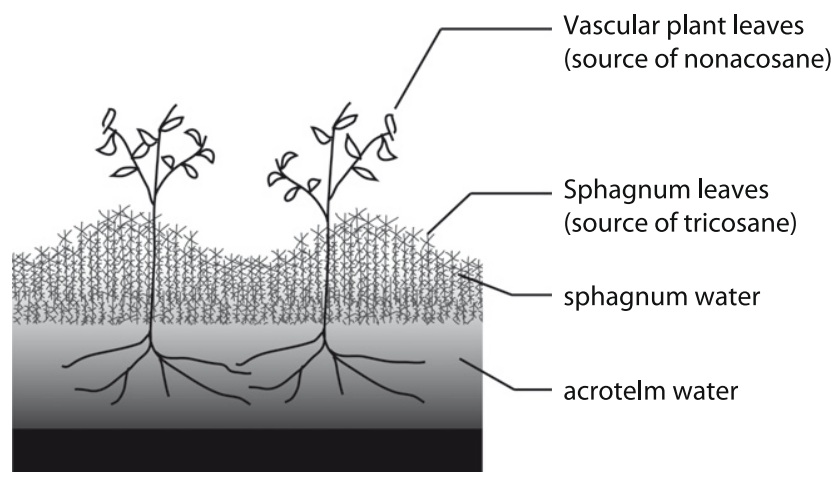

Fig. 2. This diagram of a peatland shows the relative locations of sphagnum water and acrotelm water. The region shaded with a gradient represents the acrotelm, which is variably saturated and oxygenated throughout the season. The region shaded completely black is the catotelm, or the permanently saturated and anoxic zone.

Sphagnum hyaline cells and from between adjacent leaves on branches and fascicles.

The second sample type, "acrotelm water" was obtained from the zone of depths through which the height of the water table varies seasonally. We collected water immediately below the top of the water table by digging a small ( $\sim 25 \mathrm{~cm}$ wide) trench deep enough to expose the water table. A polypropylene vial was submerged below the exposed water surface. The capped vial was sealed with polyvinyl chloride tape to avoid post-sampling evaporation.

The third type of sample, living Sphagnum, was collected from the peatland surface. Live Sphagnum from the top $20 \mathrm{~cm}$ of peat was trimmed and stored in polyethylene bags. To ensure that only the living plants were analyzed, the capitula (growing ends of the Sphagnum individuals) were separated from the older, dead parts, which were discarded. Conductivity of water samples was measured in the field, prior to filtration, using a field conductivity/pH meter.

We measured $\delta \mathrm{D}$ and $\delta^{18} \mathrm{O}$ values of sphagnum water and acrotelm water as well as the $\delta \mathrm{D}$ of $\mathrm{C}_{23} n$-alkane extracted from living Sphagnum from the surface of the 18 peatlands. We also determined $\delta \mathrm{D}$ values of $\mathrm{C}_{23}$ and $\mathrm{C}_{29}$ $n$-alkane extracted from 95 samples of a $185 \mathrm{~cm}$ core from Minden Bog. The handling of samples from the Minden Bog core is explained in detail by Nichols et al. (2006) and Booth and Jackson (2003).

Water samples were filtered with $25 \mu \mathrm{m} \mathrm{A/E}$ glass fiber filters prior to isotope analysis. Hydrogen isotope values of water samples were determined using TC/EA-IRMS following Huang et al. (2002). Water was converted to hydrogen gas by high-temperature pyrolysis in a Finnigan TC/ EA. Hydrogen gas flowed to the Finnigan Delta ${ }^{\text {plus }} X L$ gas isotope ratio mass spectrometer through a Finnigan ConFlo II module. Isotope ratios were determined by comparison with three isotope standards, VSMOW, GISP, and SLAP.

Lipids were extracted from fresh Sphagnum and peats by $24 \mathrm{~h}$ of soaking in a 9:1 solution of dichloromethane and methanol followed by 30 min of ultrasonic agitation. Total lipid extracts from both plants and peats were separated into neutral and acid fractions using a solid phase extraction column (Aminopropyl Bond Elute) (Huang et al., 2004). n-Alkanes were separated from the rest of the neutral fraction by eluting them from a silica gel flash column using hexane.
Hydrogen-isotope ratios of $n$-alkanes were determined using GC-IRMS following Huang et al. (2002) and Hou et al. (2006). Alkanes were converted to hydrogen gas in a hightemperature pyrolysis reactor as they elute from an Agilent 6800 GC. The evolved hydrogen passed to a Finnigan Delta-

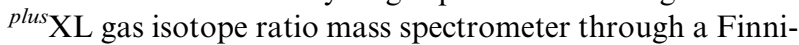
gan GC Combustion III module. The isotope ratio was determined by comparison with a laboratory reference gas which was calibrated to a certified standard. $\mathrm{H}_{3}{ }^{+}$factor was determined every $48 \mathrm{~h}$, and a laboratory standard mix of four fatty acid methyl esters was injected after every six sample injections to monitor instrument stability. Standard deviations of triplicate measurements of $n$-alkane samples in this study were, on average, $3.8 \%$.

Oxygen isotope values for water samples were determined by equilibrating $5 \mathrm{~mL}$ samples with $\mathrm{CO}_{2}$ of known isotopic composition for $24 \mathrm{~h}$ (Socki et al., 1992; Gehre et al., 2004). Samples were then analyzed on a Finnigan

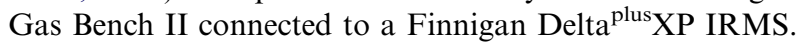
The precision of $\delta^{18} \mathrm{O}$ in waters, based on duplicate analysis of samples, was $\pm 0.06 \%$. The age model for the Minden core was based on 10 accelerator mass spectrometry (AMS) radiocarbon dates (Booth and Jackson, 2003).

To better constrain the apparent fractionation between sphagnum water and tricosane, we grew Sphagnum spp. under controlled conditions. Pure deuterium oxide (Aldrich) was diluted with water from the Providence, RI municipal water supply. Sphagnum spp. ordered from Carolina Biological Supply were grown in six polypropylene containers and were irrigated daily with six different waters of increasing $\delta \mathrm{D}$ values. Each container was kept in a closed, translucent, cylindrical, polypropylene container $(25 \times 45 \mathrm{~cm})$ to reduce evaporation while all six containers were held in a growth chamber set for $12 \mathrm{~h}$ of light, $12 \mathrm{~h}$ of dark, $15^{\circ} \mathrm{C}$, and $80 \%$ humidity for 2 weeks. After the 2-week period, new Sphagnum growth $(\sim 3-5 \mathrm{~cm})$ was trimmed, and the hydrogen-isotope ratios of tricosane and the irrigation water were measured according to the same procedures as described for the environmental samples.

\section{RESULTS AND DISCUSSION}

For the purposes of this discussion, we use the following water budget for a peatland: 
$S=(P-T-Q) \times f$

where:

$S \quad$ surface water storage

$P \quad$ precipitation

$T \quad$ transpiration

$Q \quad$ infiltration to lower peatland levels, seepage, and outflow

$f \quad$ fraction remaining after evaporation

Evaporation and transpiration are separated in our budget because transpiration does not have an associated isotopic enrichment, while evaporation does. The $Q$ term refers to water that infiltrates down into the catotelm or flows laterally out the edges of the acrotelm into the surrounding moat. Note that the $f$ term, the evaporative term we will be reconstructing, is representing the fraction of water evaporated from the surface only. It does not represent evaporative loss relative to the entire budget, but relative to the water remaining in the surface layer of the peatland that has not infiltrated deeper into the peatland.

\subsection{Comparison of sphagnum water and acrotelm water}

The $\mathrm{H}$ and $\mathrm{O}$ isotopic ratios of modern sphagnum and acrotelm water from 18 peatlands are displayed in Supplementary Table 1 . When acrotelm and sphagnum water isotope data are compared with the local meteoric water line, distinct differences between the two reservoirs become apparent (Fig. 3). Sphagnum water is systematically more enriched in both deuterium and ${ }^{18} \mathrm{O}$ than water from the acrotelm below. Sphagnum water sampled from hummock microenvironments is also enriched relative to sphagnum water sampled from hollow microenvironments. The slope of the linear relationship between the $\delta \mathrm{D}$ and $\delta^{18} \mathrm{O}$ values for acrotelm water (7.6) is the same as the slope of the local meteoric water line (7.6), indicating little evaporative isotopic enrichment. However, the slope of the lines fit to the sphagnum water sample data is much lower (4.7), indicating that sphagnum water has been subjected to substantial evaporative enrichment. As these two reservoirs represent peatland surface water before and after the effect of evaporation, we can therefore use the $\delta \mathrm{D}$ values of the water in these reservoirs to calculate $f$, the fraction of water remaining after evaporation from the surface of the peatland, using an evaporation model that will be discussed in sections below. First, we will discuss reconstructing sphagnum and acrotelm water $\delta \mathrm{D}$ using the $\delta \mathrm{D}$ of lipid biomarkers.

\subsection{Reconstructing sphagnum water from tricosane}

We chose to use the $\delta \mathrm{D}$ of a Sphagnum biomarker, tricosane, to reconstruct the $\delta \mathrm{D}$ of sphagnum water. Because this is the water used by Sphagnum for photosynthesis, Sphagnum leaf wax biomarkers are an ideal way of tracking the $\delta \mathrm{D}$ of sphagnum water through time. Previous studies have shown that $\mathrm{C}_{23} n$-alkane can be used as a valid biomarker for Sphagnum plants (Baas et al., 2000; Nott et al., 2000; Pancost et al., 2002; Nichols et al., 2006). Further, tricosane has been used as a biomarker for Sphagnum in previous hydrogen isotope studies in peatlands (Xie et al., 2000, 2004). Fig. 4 shows a plot of the $\delta \mathrm{D}$ of tricosane versus the $\delta \mathrm{D}$ of sphagnum water at the 18 Midwestern peatland sites, plotted together with the experimentally grown Sphagnum. It is likely that there is multi-step biosynthetic fractionation between the Sphagnum water and Sphagnum leaf waxes (Zhang and Sachs, 2007). To simplify these fractionations, we calculated an empirical relationship $\left(r^{2}=0.3, p=0.01\right)$ to convert the $\delta \mathrm{D}$ of $\mathrm{C}_{23} n$-alkane into the $\delta \mathrm{D}$ of sphagnum water from the calibration sites, rather than calculating net fractionation for each sample. The slope of experimental relationship is similar to that of the

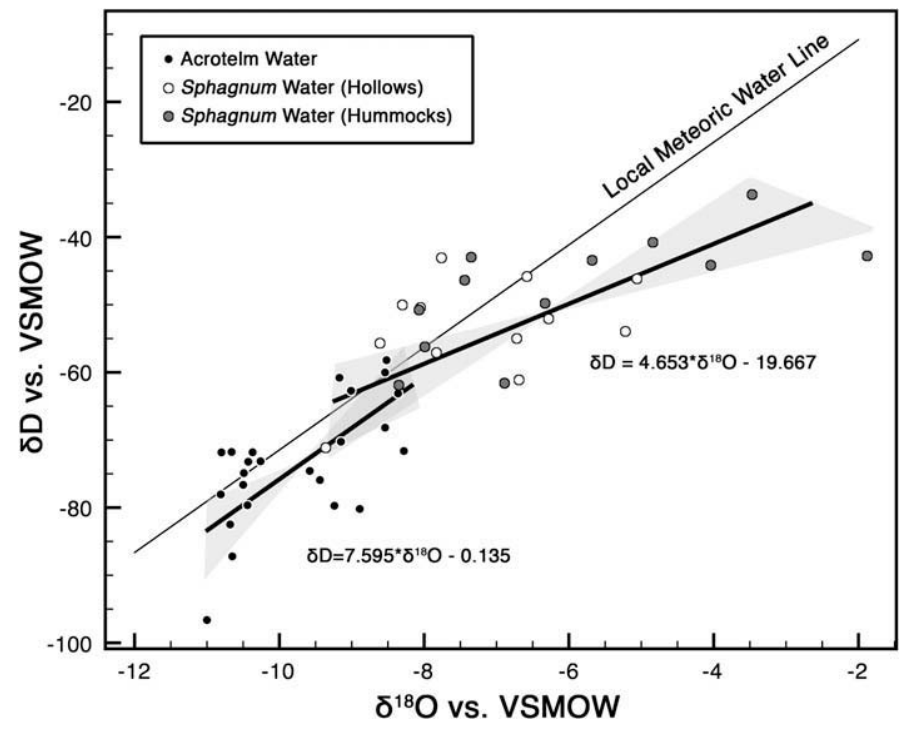

Fig. 3. Stable isotope measurements of acrotelm and living sphagnum water samples. Living sphagnum water samples are separated into those from "hummock" microenvironments and "hollow" microenvironments. 


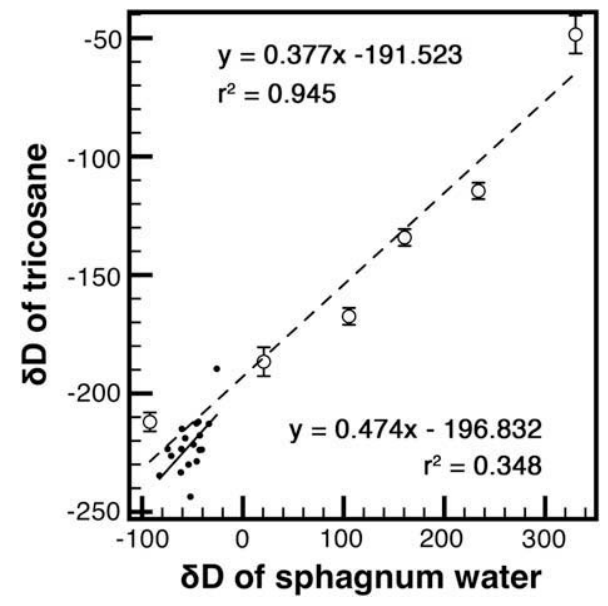

Fig. 4. Plot of the relationship between the $\delta \mathrm{D}$ of $\mathrm{C}_{23} n$-alkane collected from Midwestern peatlands and the $\delta \mathrm{D}$ of sphagnum water at the same location (black points) and the relationship between the $\delta \mathrm{D}$ of tricosane in the lab-grown Sphagnum and the $\delta \mathrm{D}$ of the water used for irrigation (white points). Error bars indicate analytical error for both $\delta \mathrm{D}$ of water and lipids. Where bars are not visible, error is smaller than the size of the marker.

field samples, but is much better constrained $\left(r^{2}=0.9\right.$; $p=0.001)$. We have used the relationship resulting from this experiment to reconstruct sphagnum water in our downcore study, although this relationship extends beyond the range of variability expected in nature. However, the model of evaporation is not particularly sensitive to the differences in the regression used for reconstructing sphagnum water (i.e., using the field-derived and the laboratory-derived regression yield similar results).

\subsection{Reconstructing acrotelm water from nonacosane}

The $\delta \mathrm{D}$ values of leaf wax compounds from vascular plants have been shown by several studies (Sachse et al., 2006; Hou et al., 2008) to reflect the $\delta \mathrm{D}$ value of the local precipitation after taking into consideration an approximately $100 \%$ apparent isotopic fractionation. Thus, to reconstruct the $\delta \mathrm{D}$ of acrotelm water, we use the $\delta \mathrm{D}$ of $\mathrm{C}_{29}$ n-alkane, a biomarker for vascular plants (Baas et al., 2000; Nott et al., 2000; Pancost et al., 2002; Nichols et al., 2006). Several other factors, such as differing vascular plant species and relative humidity, could also affect $\delta \mathrm{D}$ values of vascular plant leaf waxes. However, peatlands have low vascular plant species diversity (Davis and Anderson, 2001). The simplicity of plant assemblages in ombrotrophic peatlands, with Ericaceae overwhelmingly dominating, however, minimizes the effect of vegetation on the isotope ratios of vascular plant biomarkers. Growth experiments by Hou et al. (2008) showed that the impact of relative humidity on plant leaf wax $\delta \mathrm{D}$ is small $(5.7 \%$ for a $50 \%$ difference in relative humidity). For these reasons, we interpret the $\delta \mathrm{D}$ of vascular plant leaf waxes in our ombrotrophic sediments (specifically, nonacosane) to essentially reflect the $\delta \mathrm{D}$ of acrotelm water after correcting for a constant apparent enrichment factor.
Contrasting the $\delta \mathrm{D}$ of tricosane and nonacosane, allows us to cancel out the common influence factors (e.g., precipitation $\delta \mathrm{D})$, and focus only on the evaporative enrichment. In the following sections we will discuss calculating a hydrologic parameter - the amount of evaporation from the peatland surface water-using the contrast between the reconstructed $\delta \mathrm{D}$ of sphagnum and acrotelm water.

\subsection{Estimating evaporation using sphagnum and acrotelm waters}

If the acrotelm water carries the isotopic signal of precipitation on the peatland, and sphagnum water represents the post-evaporation reservoir, we can then calculate the amount of water evaporated from the surface of the bog. Fig. 5 shows a schematic of hydrogen isotope enrichments and depletions that occur in the peatland system. To make the calculation to quantify evaporation, however, we must choose a model that appropriately simulates the conditions under which the water is evaporating. In this section, we explore two different models to approximate the evaporation of sphagnum water: the "Craig and Gordon model," (Craig and Gordon, 1965) and the "Rayleigh model" (Clark and Fritz, 1997). The key difference between these two models is that the modified Craig and Gordon model accounts for re-condensation of vapor back into the reservoir, while the Rayleigh model does not.

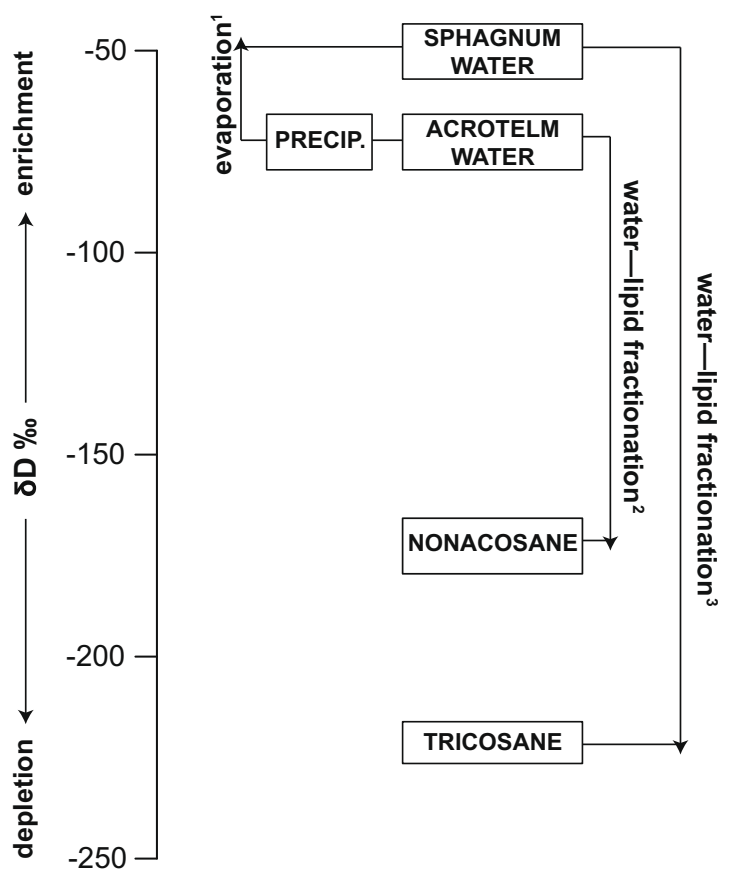

Fig. 5. This schematic shows the approximate $\delta \mathrm{D}$ values for all the species measured in this study. The various enrichments and depletions are numbered: 1 , sphagnum water is enriched relative to precipitation/acrotelm water by evaporation; 2, nonacosane is depleted relative to acrotelm water during biosynthesis and other processes occurring in the plant; 3 , tricosane is depleted relative to sphagnum water as a result of biosynthesis. 
An effective model must accurately simulate evaporative isotopic effects from Sphagnum leaves. Leaf water evaporation from the leaves of vascular plants has been studied extensively, and it has been widely accepted that the modified Craig and Gordon model closely approximates this evaporative process in vascular plants (Craig and Gordon, 1965; Roden et al., 2000; Smith and Freeman, 2006; Hou et al., 2008). However, the physiologic differences between Sphagnum and vascular plants render some of the assumptions made in the modified Craig and Gordon model inappropriate to apply in this study.

The key difference between Sphagnum and vascular plants is that Sphagnum lacks the stomata of vascular plants. Use of stomata causes a strong interaction (both evaporation and re-condensation) of ambient humidity with leaf water. When stomata are open, water vapor escapes while $\mathrm{CO}_{2}$ is allowed to enter the leaf. The average ratio of diffusion rates between $\mathrm{CO}_{2}$ and $\mathrm{H}_{2} \mathrm{O}$ is $1: 1.6$ (Farquhar et al., 1989). This is consistent with the rationale behind the Craig-Gordon model: ambient moisture can readily re-condense into the evaporating pool of water.

The Sphagnum hydraulic system is, however, very different from that of vascular plants. Like other ectohydric mosses, Sphagnum can assimilate carbon from dissolved inorganic carbon (DIC), rather than gaseous $\mathrm{CO}_{2}$, and hence does not control access to atmospheric $\mathrm{CO}_{2}$ (Proctor, 2000). Water in Sphagnum leaves is held in specialized hyalinewater-holding - cells which have pores with fixed (1-12 $\mu \mathrm{m})$ openings (Hayward and Clymo, 1982). During the time of rainfall, the hyaline cells of Sphagnum rapidly soak up water. Over time, water evaporates through the tiny pores in the hyaline cells. However, as the water evaporates, the surface tension of the diminishing water inside the cell pulls the cell walls inward, keeping gasses out of the cell, preventing interaction of atmospheric humidity with the evaporating reservoir. Atmospheric gasses do not enter the Sphagnum leaf directly until the water has completely dried. Also, as the surface of the peatland dries, the entire unsaturated zone of the peatland shrinks, making up for the volume previously occupied by water (Clymo and Hayward, 1982). Sphagnum can completely desiccate and revive upon rewetting (Clymo and Hayward, 1982). Since Sphagnum peatlands generally only occur in high humidity regions (annual average of $70-80 \%$ relative humidity), complete desiccation would have been nearly impossible had ambient moisture been allowed to condense back into the hyaline cells of the Sphagnum. Given the differences in the gas and water exchange characteristics between Sphagnum and vascular plants, we hypothesize that a Rayleigh-type model, which ignores re-condensation of ambient humidity, would more accurately simulate evaporation of sphagnum water. We will test this hypothesis in the following sections.

\subsubsection{Craig and Gordon model}

The equation for the calculation of $f$, or the fraction of the original reservoir remaining after evaporation, using the Craig and Gordon model is as follows (Craig and Gordon, 1965).

$\ln f=\frac{\ln \left(\delta \mathrm{D}_{\mathrm{s}}-\frac{A}{B}\right)-\ln \left(\delta \mathrm{D}_{\mathrm{a}}-\frac{A}{B}\right)}{B}$

$$
\begin{array}{ll}
\text { where: } & h \times \delta \mathrm{D}_{A}+\varepsilon_{\mathrm{k}}+\frac{\varepsilon^{*}}{\alpha} \\
A \quad \frac{h+h+\varepsilon_{\mathrm{k}}}{1-\varepsilon_{\mathrm{k}}-\frac{\varepsilon^{*}}{\alpha}} \\
B \quad \frac{h+\varepsilon_{\mathrm{k}}}{1-h+}
\end{array}
$$

$\delta \mathrm{D}_{\mathrm{s}} \quad$ isotope ratio of sphagnum water

$\delta \mathrm{D}_{\mathrm{a}}$ isotope ratio of acrotelm water

$\delta \mathrm{D}_{\mathrm{A}}$ isotope ratio of the evaporate

$h$ relative humidity $=0.75$ ombrotrophic bogs only occur in areas which have an annual average relative humidity of $0.7-0.8$ (Halsey et al., 2000)

$\varepsilon_{\mathrm{k}} \quad$ kinetic enrichment factor $=3.125$

$\varepsilon^{*} \quad$ equilibrium enrichment factor $=86.731$

$\alpha \quad$ equilibrium fractionation factor $=1.086731$

We chose $290 \mathrm{~K}$ as an average growing season temperature for cool temperate peatlands, giving an equilibrium fractionation factor of $86.731 \%$. It is the average May-October temperature at Flint, MI, the closest weather station to the Minden Bog location. While changing temperature does affect the output of the model, a $1{ }^{\circ} \mathrm{C}$ temperature change produces a very small $(\sim 0.006)$ change in $f$. Therefore, changes of temperature of a few degrees will have no discernable effect on our evaluation of evaporation.

Craig-Gordon-type models take into account ambient humidity interacting with the liquid reservoir. Although the Craig and Gordon model has been shown to be appropriate for leaf water evaporation in vascular plants, it has never been applied to quantify water evaporation from Sphagnum. The fundamental assumption that ambient moisture exchanges with the residual pool of evaporative water in the Craig and Gordon model, however, does not necessarily apply to Sphagnum, due to the hyaline cells shrinking in response to the lost water volume, as described above.

\subsubsection{Rayleigh model}

In contrast to the Craig-Gordon model, the Rayleigh model assumes no interaction of vapor with remaining liquid. As vapor is formed, it is immediately removed from the system.

$\ln f=\frac{\delta \mathrm{D}_{\mathrm{a}}-\delta \mathrm{D}_{\mathrm{s}}}{\varepsilon_{\mathrm{k}}+\varepsilon^{*}}$

where:

$\delta \mathrm{D}_{\mathrm{a}} \quad$ isotope ratio of acrotelm water (representing precipitation)

$\delta \mathrm{D}_{\mathrm{s}} \quad$ isotope ratio of Sphagnum water

$\varepsilon_{\mathrm{k}} \quad$ kinetic enrichment factor $=3.125$

$\varepsilon^{*} \quad$ equilibrium enrichment factor $=86.731$

\subsection{Testing the applicability of Craig-Gordon versus Rayleigh models for Sphagnum-dominated peatlands}

We calculated the fraction of water remaining after evaporation $(f)$ for our modern water calibration samples using both the Craig and Gordon model and the Rayleigh model. We compared the estimates of $f$ from the two models to the measurements of the conductivity of sphagnum 


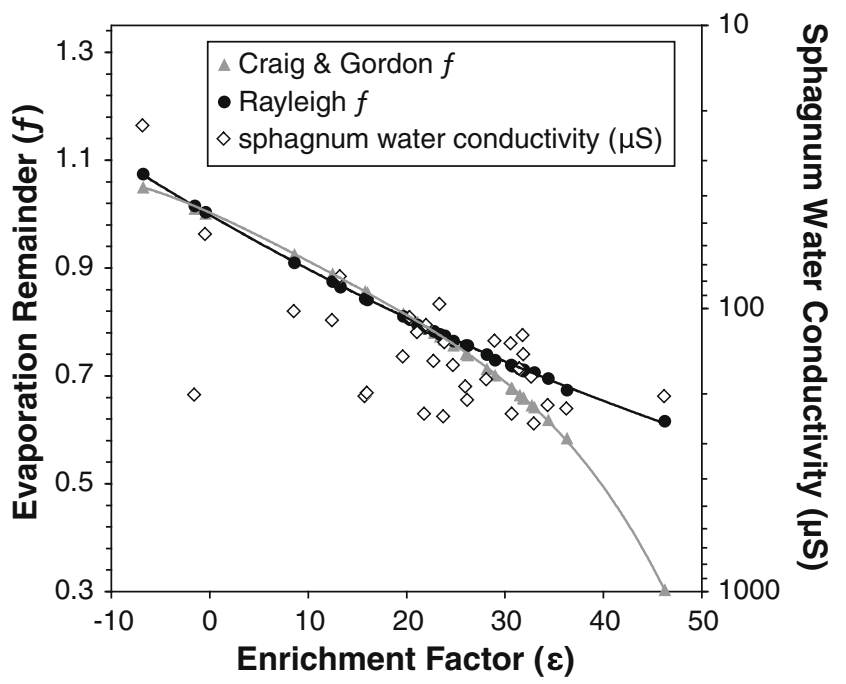

Fig. 6. The fraction remaining after evaporation calculated by two models, the Craig and Gordon-type model (gray) and Rayleigh model (black), as well as the conductivity of the sphagnum water (white) are plotted against the isotope enrichment $(\varepsilon)$ between the acrotelm and the sphagnum for water from 18 modern bogs.

water, which also increases with evaporation. Because evaporation increases the enrichment factor $(\varepsilon)$ between $\delta_{\mathrm{a}}$ and $\delta_{\mathrm{s}}$, we plotted the outputs of the two stable isotope models and conductivity against the hydrogen isotope enrichment (ع) between $\delta_{\mathrm{a}}$ and $\delta_{\mathrm{s}}$ (Fig. 6). Both Craig-Gordon and Rayleigh models yield similar outputs of $f$ for sampling sites with $\varepsilon<25 \%$, and both decrease with conductivity. When $\varepsilon>25 \%$, however, the outputs from the Craig and Gordon model and Rayleigh model deviate. The Craig and Gordon model requires increasingly larger fractions of water loss in order to yield the observed isotopic differentiation (Fig. 6). This is not surprising since condensation of ambient moisture back to the evaporating pool of water dampens the rate of isotopic enrichment. When the isotope enrichment is large $(>50 \%)$, the Craig and Gordon model yields undefined values (i.e., the model requires more than $100 \%$ of the water to be evaporated to produce the observed change in isotope values). In contrast, the Rayleigh model yields reasonable $f$ values for all the calibration samples - this is consistent with the fact that $f$ values computed using the Rayleigh model trend closely with conductivity variations (Fig. 6).

\subsection{Application of the evaporation isotopic model to downcore isotope measurements}

Once lipid $\delta \mathrm{D}$ values had been converted into water $\delta \mathrm{D}$ values using the linear relationship in Fig. 4 for sphagnum water and an enrichment factor of $-100 \%$ for vascular plants, we calculated $f$ values for each downcore sample from Minden Bog using our Rayleigh-type model (Fig. 7). The record of $f$ for Minden Bog follows the general trends of the other measures of paleohydrology, Sphagnum/Vascular Ratio (SVR) and testate amoebae-inferred water table depth. Differences between the record of $f$ and the record of water table depth can be attributed to their measuring different parts of the hydrologic budget. Water table depth is a measure of the total storage of the peatland, while $f$ is only a measure of the surface water loss by evaporation. It does not include other losses, such as seepage or transpiration by vascular plants. When the reconstructed $f$ is, for example, 0.2 , this does not mean that $80 \%$ of all the peatland's water has been evaporated. The volume of water represented by $f=1$ is the amount of water left in the surface of the bog after infiltration, seepage, and transpiration have been subtracted from the budget. The similarities between $f$ and other measures of paleohydrology lend credence to $f$ as a measure of paleohydrology, while the contrasts stress the importance of multiproxy reconstructions, although we find that many of the drier parts of the record fall outside of the range of our calibration set. Hopefully this limitation can be remedied in future studies with a calibration set that is expanded to include sites that experience more evaporation.

\subsection{Summary of assumptions and areas for further improvement}

Though this new proxy for surface evaporation represents an important advance in our understanding of changing hydrology of peatlands, there are several assumptions involved with this method. Regarding the apparent fractionation between the $\delta \mathrm{D}$ of nonacosane and acrotelm water, it is known that sedges (and other Poales) have a distinct apparent fractionation between water and waxes than other plants (Hou et al., 2008). It could be possible to more accurately reconstruct acrotelm water using biomarkers specific to particular plant functional types (e.g., sedges or ericads). The apparent fractionation between sphagnum water and tricosane could also be improved, as it is currently based on our single growth chamber experiment, and the field relationship had an $r^{2}$ of only $30 \%$. Our evaporation model could be improved with an expanded field calibration set including more strongly evaporated sites, as mentioned above. The measurement of $f$ itself is also 


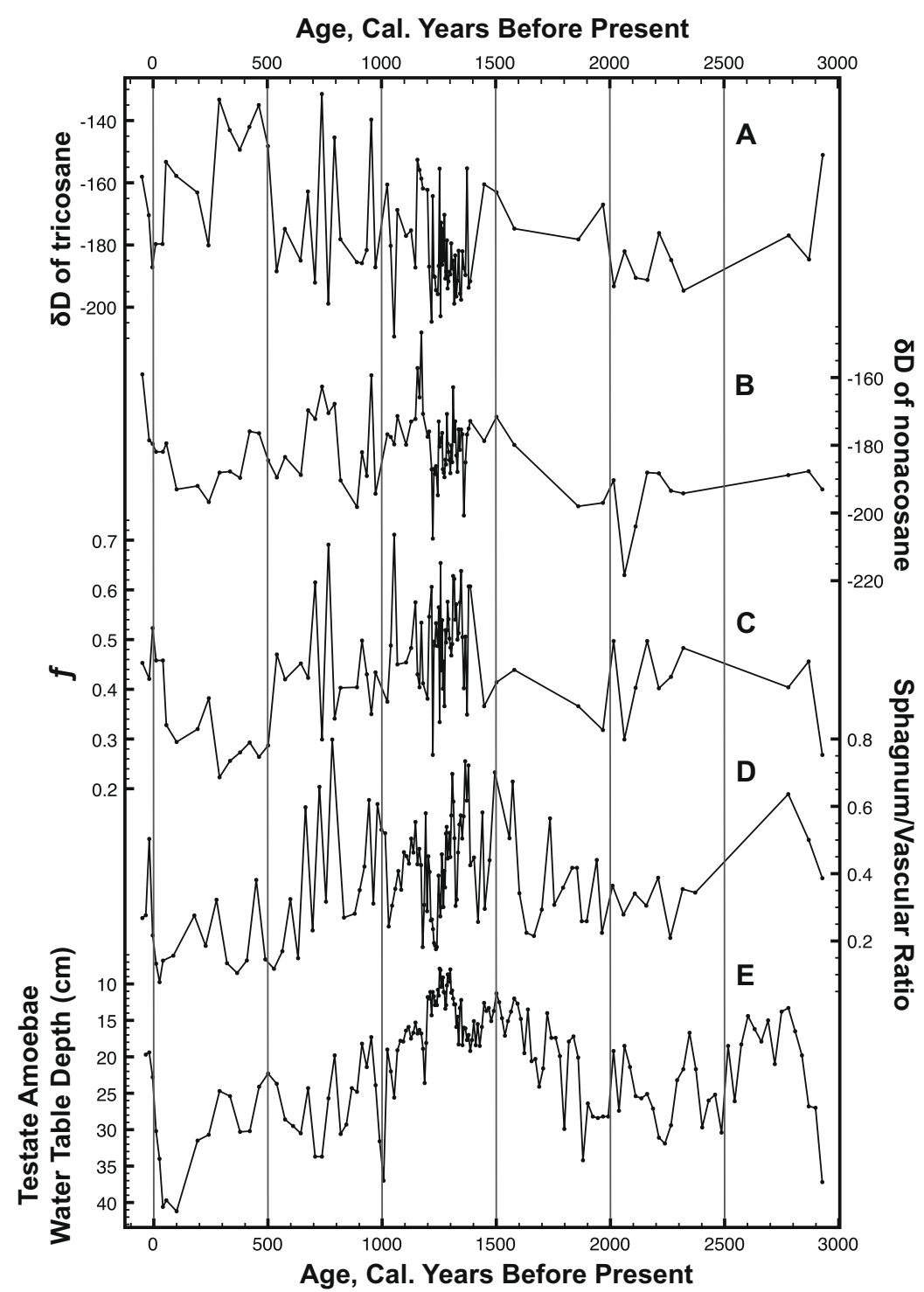

Fig. 7. (A) $\delta \mathrm{D}$ measurements of $\mathrm{C}_{23} n$-alkane. (B) $\delta \mathrm{D}$ measurements of $\mathrm{C}_{29} n$-alkane. (C) Calculation of fraction of water remaining $(f)$ from Minden Bog. (D) Sphagnum/Vascular Ratio (SVR) showing the relative abundance of Sphagnum to vascular plant $n$-alkanes (Nichols et al., 2006). (E) Water table depth reconstruction by testate amoebae method (Booth and Jackson, 2003).

limited by its place in the hydrologic budget. A value $f=1$ still only refers to the amount of water held at the surface by Sphagnum's capillary action. It would be ideal to be able to use $f$ along with the testate amoebae-inferred water table depth to calculate precipitation amount, but unfortunately the outflow or seepage term and the transpiration term are still unknown. Still, $f$ provides an important measure of peatland surface evaporation, which is closely related to hydrological balance.

\section{CONCLUSIONS AND PALEOCLIMATIC SIGNIFICANCE}

We propose a new method to quantitatively reconstruct the fraction of surface water remaining after evaporation, $f$, from the surface of an ombrotrophic peat bog. This va- lue is calculated using a Rayleigh model of hydrogen isotope enrichment between water used by the living Sphagnum in the peatland and water in the acrotelm used by vascular plants of the peatland. Sphagnum water $\delta \mathrm{D}$ is reconstructed from measurements of sedimentary $\mathrm{C}_{23} n$-alkane, a biomarker for Sphagnum, while acrotelm water $\delta \mathrm{D}$ is reconstructed from isotope ratio measurements of sedimentary $\mathrm{C}_{29} n$-alkane, a biomarker for vascular plants. We propose that the Rayleigh model is appropriate for computing $f$, based on the known physiological differences between Sphagnum and vascular plants. The hyaline cells of Sphagnum, and the surface of the peatland itself, contract as water is lost, preventing ambient moisture from interacting with the residual pool in Sphagnum tissues. Isotope measurements of modern waters sampled from peatlands across the Upper Midwest provide proof-of-concept 
for our isotope model, and we confirm the utility of our proxy with downcore measurements of samples from Minden Bog and its compatibility with other climate reconstructions from the same core (testate amoebae water table depth, Sphagnum/Vascular Ratio).

Changes in the water balance at Minden Bog are likely related to changes in the atmospheric circulation that transports moist air to the Upper Midwest from the Gulf of Mexico (Booth et al., 2006). Many previous studies have posited that changes in atmospheric circulation about the Atlantic and Pacific subtropical anticyclones (Archambault et al., 2008), as well as changes in sea surface temperature in both oceans (McCabe et al., 2004) interact to produce hydroclimatic changes in eastern North America. To fully understand the mechanisms for these changes observed in the sedimentary record, we must understand the relationship between continental moisture and the interactions between sea surface temperature and atmospheric circulation. Many methods have been established for constraining changes in sea surface temperature such as alkenone unsaturation (Brassell et al., 1986), TEX86 (Powers et al., 2004), $\mathrm{Mg} / \mathrm{Ca}$ (Lea, 2003), but reconstructing atmospheric circulation by its imprint - the distribution of moisture on the continents - is less straightforward. Our new method for quantifying past evaporation can be applied to networks of sites, reconstructing changes in synoptic climate systems. These networks, in conjunction with reconstructions of past sea surface temperatures, will yield comprehensive understanding of past hydrologic change.

\section{ACKNOWLEDGMENTS}

This work was funded by NSF grants ATM-0625298, ESH0318050, 0402383, 0402660, and 0402410, EAR-0602325, and DEB-0345012. The authors would like to thank Arndt Schimmelmann and two anonymous reviewers for their insightful criticism and Megan Taylor for oxygen isotope measurements. Y. Huang thanks the Hanse-Wissenschaftskolleg, Germany, for a fellowship during which part of this manuscript was written.

\section{APPENDIX A. SUPPLEMENTARY DATA}

Supplementary data associated with this article can be found, in the online version, at doi:10.1016/j.gca.2009. 11.012 .

\section{REFERENCES}

Abbott M., Finney B., Edwards M. and Kelts K. (2000) Lake-level reconstruction and paleohydrology of Birch Lake, Central Alaska, based on seismic reflection profiles and core transects. Quatern. Res. 53, 154-166.

Alvarez Zarikian C., Swart P., Gifford J. and Blackwelder P. L. (2005) Holocene paleohydrology of Little Salt Spring, Florida, based on ostracod assemblages and stable isotopes. Palaeogeogr. Palaeoclimatol. Palaeoecol. 225, 134-156.

Archambault H. M., Bosart L. F., Keyser D. and Aiyyer A. R. (2008) Influence of large-scale flow regimes on cool-season precipitation in the Northeastern United States. Monthly Weather Rev. 136, 2945-2963.
Baas M., Pancost R., van Geel B. and Sinninghe Damsté J. S. (2000) A comparative study of lipids in Sphagnum species. Org. Geochem. 31, 535-541.

Barber K., Chambers F. and Maddy D. (2003) Holocene palaeoclimates from peat stratigraphy: macrofossil proxy climate records from three oceanic raised bogs in England and Ireland. Quatern. Sci. Rev. 22, 521-539.

Blackford J. (2000) Paleoclimatic records from peat bogs. Trends Ecol. Evol. 15, 193-198.

Booth R. K. and Jackson S. T. (2003) A high-resolution record of late-Holocene moisture variability from a Michigan raised bog, USA. Holocene 13, 863-876.

Booth R. K., Notaro M., Jackson S. and Kutzbach J. (2006) Widespread drought episodes in the western Great Lakes region during the past 2000 years: geographic extent and potential mechanisms. Earth Planet. Sci. Lett. 242, 415-427.

Booth R. K. (2007) Testate amoebae as proxies for mean annual water-table depth in Sphagnum-dominated peatlands of North America. J. Quatern. Sci. 23, 43-57.

Brassell S. C., Eglinton G., Marlowe I. T., Pflaumann U. and Sarnthein M. (1986) Molecular stratigraphy: a new tool for climatic assessment. Nature 320, 129-133.

Caseldine C., Baker A., Charman D. and Hendon D. (2000) A comparative study of optical properties of $\mathrm{NaOH}$ peat extracts: implications for humification studies. Holocene 10, 649-658.

Charman D. (2002) Peatlands and Environmental Change. John Wiley \& Sons Ltd., Chichester.

Clark I. and Fritz P. (1997) Environmental Isotopes in Hydrogeology. CRC Press, Boca Raton.

Clymo R. S. and Hayward P. M. (1982) The ecology of Sphagnum. In Bryophyte Ecology (ed. A. J. E. Smith). Chapman and Hall, New York, pp. 229-290.

Cook E., Woodhouse C., Eakin C., Meko D. and Stahle D. W. (2004) Long-term aridity changes in the Western United States. Science 306, 1015-1018.

Cook E., Meko D., Stahle D. and Cleaveland M. (1999) Drought reconstructions for the continental United States. J. Climate 12, $1145-1162$.

Craig H. and Gordon L. I. (1965) Deuterium and oxygen-18 variations in the ocean and the marine atmosphere. In Proceedings of a Conference on Stable Isotopes in Oceanographic Studies and Paleotemperatures, vol. 9-130, Spoleto, Italy (ed. E. Tongiorgi). Consiglio Nazional delle Richerche, Pisa, pp. 9130.

Davis R. B. and Anderson D. S. (2001) Classification and distribution of freshwater peatlands in Maine. Northeast. Nat. 8, $1-50$.

Farquhar G. D., Ehleringer J. R. and Hubick K. T. (1989) Carbon isotope discrimination in photosynthesis. Ann. Rev. Plant Physiol. Plant Mol. Biol. 40, 503-537.

Fritz S. (1996) Paleolimnological records of climatic change in North America. Limnol. Oceanogr. 41, 882-889.

Gehre M., Geilmann H., Richter J., Werner R. A. and Brand W. A. (2004) Continuous flow ${ }^{2} \mathrm{H} /{ }^{1} \mathrm{H}$ and ${ }^{18} \mathrm{O} /{ }^{16} \mathrm{O}$ analysis of water samples with dual inlet precision. Rapid Commun. Mass Spectrom. 18, 2650-2660.

Halsey L. A., Vitt D. H. and Gignac L. D. (2000) Sphagnumdominated peatlands in North America since the last glacial maximum: their occurrence and extent. Bryologist 103, 334352.

Hayward P. M. and Clymo R. (1982) Profiles of water content and pore size in Sphagnum and peat, and their relation to peat bog ecology. Proc. Roy. Soc. Lond. Ser. B Biol. Sci. 215, 299-325.

Hou J., Huang Y., Wang Y., Shuman B., Oswald W. W., Faison E. and Foster D. R. (2006) Postglacial climate reconstruction based on compound-specific $\mathrm{D} / \mathrm{H}$ ratios of fatty acids from 
Blood Pond, New England, 2006. Geochem. Geophys. Geosyst. 7, 1-11.

Hou J., D'Andrea W. and Huang Y. (2008) Can sedimentary leaf waxes record $\mathrm{D} / \mathrm{H}$ ratios of continental precipitation? Field, model, and experimental assessments. Geochim. Cosmochim. Acta 72, 3503-3517.

Huang Y., Shuman B., Wang Y. and Webb, III, T. (2002) Hydrogen isotope ratios of palmitic acid in lacustrine sediments record late quaternary climate variations. Geology 30, 11031106.

Huang Y., Shuman B., Wang Y. and Webb, III, T. (2004) Hydrogen isotope ratios of individual lipids in lake sediments as novel tracers of climatic and environmental change: a surface sediment test. J. Paleolim. 31, 363-375.

Last, W. M. and Smol, J. P. (eds.) (2002) Tracking Environmental Change Using Lake Sediments. Kluwer, Dordrecht.

Lea D. W. (2003) Elemental and isotopic proxies of marine temperatures. In The Oceans and Marine Geochemistry, vol. 6 (ed. H. Elderfield), pp. 365-390. In Treatise on Geochemistry (eds. H. D. Holland and K. K. Tuerekian). Elsevier-Pergamon, Oxford.

McCabe G. J., Palecki M. A. and Betancourt J. L. (2004) Pacific and Atlantic Ocean influences on multidecadal drought frequency in the United States. Proc. Natl. Acad. Sci. USA 101, 4136-4141.

Nichols J. E., Booth R. K., Jackson S. T., Pendall E. G. and Huang Y. (2006) Paleohydrologic reconstruction based on $n$-alkane distributions in ombrotrophic peat. Org. Geochem. 37, 15051513.

Nott C. J., Xie S., Avsejs L. A., Maddy D., Chambers F. M. and Evershed R. P. (2000) $N$-alkane distribution in ombrotrophic mires as indicators of vegetation change related to climatic variation. Org. Geochem. 31, 231-235.

Pancost R., Baas M., van Geel B. and Sinninghe Damste J. S. (2002) Bioarkers as proxies for plant inputs to peats: an example from a sub-boreal ombrotrophic bog. Org. Geochem. 33, 675-690.

Powers L. A., Werne J. P., Johnson T. C., Hopmans E. C., Sinninghe Damsté J. S. and Schouten S. (2004) Crenarchaeotal lipids in lake sediments: a new paleotemperature proxy for continental paleoclimate reconstruction? Geology 32, 613-616.
Proctor M. C. F. (2000) Physiological ecology. In Bryophyte Biology (eds. A. J. Shaw and B. Goffinet). Cambridge University Press, Cambridge, pp. 225-247.

Roden J., Lin G. and Ehleringer J. (2000) A mechanistic model for interpretation of hydrogen and oxygen isotope ratios in treering cellulose. Geochim. Cosmochim. Acta 64, 21-35.

Sachse D., Radke J. and Gleixner G. (2006) $\delta$ D values of individual $n$-alkanes from terrestrial plants along a climatic gradientimplications for the sedimentary biomarker record. Org. Geochem. 37, 469-483.

Shindell D. T., Faluvegi G., Miller R. L., Schmidt G. A., Hansen J. E. and Sun S. (2006) Solar and anthropogenic forcing of tropical hydrology. Geophys. Res. Lett. 33, 1-5.

Shuman B., Newby P., Huang Y. and Webb, III, T. (2004) Evidence for the close climatic control of New England vegetation history. Ecology 85, 1297-1310.

Smith F. and Freeman K. (2006) Influence of physiology and climate on $\delta \mathrm{D}$ of leaf wax $n$-alkanes from $\mathrm{C} 3$ and $\mathrm{C} 4$ grasses. Geochim. Cosmochim. Acta 70, 1172-1187.

Socki R. A., Karlsson H. R. and Gibson, Jr., E. K. (1992) Extraction technique for the determination of oxygen-18 in water using pre-evacuated glass vials. Anal. Chem. 64, 829-831.

Xie S., Nott C. J., Avsejs L. A., Volders F., Maddy D., Chambers F. M., Gledhill A., Carter J. F. and Evershed R. P. (2000) Palaeoclimate records in compound-specific delta $\mathrm{D}$ values of a lipid biomarker in ombrotrophic peat. Org. Geochem. 31, 10531057.

Xie S., Nott C., Avsejs L., Maddy D., Chambers F. and Evershed R. P. (2004) Molecular and isotopic stratigraphy in an ombrotrophic mire for paleoclimate reconstruction. Geochim. Cosmochim. Acta 68, 2849-2862.

Yu Z. and Ito E. (1999) Possible solar forcing of century-scale drought frequency in the Northern Great Plains. Geology 27, 263-266.

Zhang Z. and Sachs J. P. (2007) Hydrogen isotope fractionation in freshwater algae. I. Variations among lipids and species. Org. Geochem. 38, 582-608.

Associate editor: Josef Werne 